\title{
Effect of feeding egg yolk on total plasma cholesterol and atherosclerosis in young rabbits
}

\author{
Tadeusz Jezierski and Anna M. Konecka
}

\author{
Institute of Genetics and Animal Breeding, Polish Academy of Sciences \\ Jastrzębiec, 05-551 Mroków, Poland
}

(Received 17 October 1994; accepted 19 December 1994)

\begin{abstract}
The experiment was aimed primarily at inducing moderate atherosclerosis to investigate the role of behavioural and emotional factors in diet-induced atherosclerosis in rabbits. The experimental rabbits (group $\mathrm{E}, \mathrm{n}=10$ ) were offered $130 \mathrm{~g}$ standard pelleted feed mixed with 1 egg yolk daily, whereas the control rabbits (group $C, n=9$ ) were fed the same feed but without egg yolk. Altogether the $E$ rabbits were offered $64 \mathrm{egg}$ yolks within a period of 2 months. Total plasma cholesterol was estimated before and after the experimental period. The degree of atheroma was estimated quantitatively as the percentage of the aorta surface affected. Mixing the egg yolk with pelleted feed resulted in the $\mathrm{E}$ rabbits consuming on average $20.1 \mathrm{~g}$ cholesterol during the experimental period as compared to $6.9 \mathrm{~g}$ cholestcrol consumed by $\mathrm{C}$ rabbits in normal feed. There was no significant effect of feeding egg yolk on total plasma cholesterol. A significant diet $x$ sex interaction effect $(P=0.013)$ on total plasma cholesterol after the experimental period was found. Not one of the rabbits either group $\mathrm{E}$ or $\mathrm{C}$ developed visible atherosclerosis.
\end{abstract}

KEY WORDS: egg yolk, feeding, plasma cholesterol, atherosclerosis, rabbits

\section{INTRODUCTION}

When using rabbits as models for studying the effect of behavioural and emotional factors on diet-induced atherosclerosis we found large individual differences in cholesterol consumed in feed and in atheroma size (Jezierski et al., 1993). The present experiment was aimed primarily at inducing moderate atherosclerosis, to make the effects of behavioural and emotional factors more discernible. This was attempted by using a simple method of inducing atherosclerosis in rabbits by feeding them one egg yolk daily mixed with normal, pelleted feed (Cornhill and Roach, 1974). 
According to some recommendations for preventing coronary heart disease in humans, the daily intake of cholesterol should not exceed $300 \mathrm{mg}$ (Brown, 1990; Cannon, 1990). Since egg yolk contains about $200-250 \mathrm{mg}$ cholesterol, the general opinion is that eggs are a major source of dietary cholesterol, which may be responsible for inducing atherosclerosis. This opinion has led to a decline in egg consumption (Griffin, 1992). Many attempts have been made to reduce egg yolk cholesterol by feeding hens special diets, by pharmacological intervention and/or by genctic selection (Hargis, 1988). A question arises how far these manipulations of egg cholesterol are substantiated by the effects of egg consumption on changes in plasma cholesterol and, particularly, on inducing atherosclerosis. So far the majority of papers have discussed the influence of an egg diet on plasma cholesterol but this is rather a marker of risk for atherosclerosis and not its cause (Sieber, 1993).

In the present work, relationships between egg consumption, total plasma cholesterol and atheroma size were investigated in rabbits as a model.

\section{MATERIAL AND METHODS}

Nineteen White New Zeland rabbits (11 males and 8 females) stemming from the Institute's own outbred stock were used. The animals were three months old at the beginning of the experiment. The rabbits were kept in individual wire cages $60 \mathrm{~cm} \times 60 \mathrm{~cm} \times 32 \mathrm{~cm}$ at an average room temperature of $14-18^{\circ} \mathrm{C}$. Water was available ad libitum. Between weaning and the beginning of the experiment the rabbits were fed ad libitum with standard pelleted rabbit feed containing $18.0 \%$ crude protein, $4.2 \%$ fat and $13.1 \%$ crude fibre.

During the experimental period lasting 2 months 10 rabbits ( $\mathrm{E}=$ experimental group) were offered $130 \mathrm{~g}$ pelleted feed daily mixed with 1 egg yolk obtained from a commercial line of hens and dried for 12 hours, while the remaining 9 rabbits were fed the same feed without the egg yolk $(\mathrm{C}=$ controls). Since the rabbits sometimes did not consume their full daily dose, the unconsumed feed was weighed. Altogether the rabbits were offered 64 egg yolks. All the rabbits were weighed weekly.

Blood samples were taken into heparinized tubes from an ear vein before and after the experimental period. Prior to blood sampling the rabbits fasted for 24 hours. After collection, the blood samples were centrifuged at $3000 \mathrm{xg}$ for $15 \mathrm{~min}$. Total plasma cholesterol content in $\mathrm{mg} / 100 \mathrm{ml}$ was measured in triplicate using Biochemtest No. 1344-690-718061 (POCh, Gliwice, Poland). The intra assay variability was $2 \%$. Analysis of the food revealed that the diet for $\mathrm{E}$ rabbits contained 295 (S.D. $=39) \mathrm{mg}$ cholesterol $/ 100 \mathrm{~g}$ dry feed and the diet for $\mathrm{C}$ rabbits contained $98($ S.D. $=7.2) \mathrm{mg}$ cholesterol $/ 100 \mathrm{~g}$ dry feed. 
After killing each rabbit, the aorta ascendens, arcus aortae and aorta descendens up to the 6 th or 7 th arteria intercostalis were removed and dissected. These arteries were stained with oil-red $O$ (Romcis, 1968), pinned out and photographed in colour. Two colour tints were distinguised: (a) deep red indicating severe atheroma and (b) pink or pale indicating weak or no atheroma. Atheroma size was estimated by placing a transparent grid over the photograph, counting the deep red squares and presenting them as a percentage of the total number of counted squares.

For the statistical analysis of feed consumption, weight gains, total plasma cholesterol and atheroma size the following mixed - model two-way analysis of variance was used:

$\mathrm{Y}(\mathrm{ijk})=\mathrm{u}+\mathrm{F}(\mathrm{i})+\mathrm{S}(\mathrm{j})+\mathrm{FS}(\mathrm{ij})+\mathrm{e}(\mathrm{ijk})$

where:

u - mean value

F(i) - effect of diet $(i=1,2)$ - fixed effect

$\mathrm{S}(\mathrm{j}) \quad$ - effect of sex $(j=1,2)$ - random effect

FS(ij) - effects of feeding $x$ sex interaction

e(ijk) - error

Also, correlation coefficients between the investigated traits were calculated.

\section{RESULTS AND DISCUSSION}

Feed consumption, weight gains and feed efficiency (feed per $1 \mathrm{~g}$ weight gain) did not differ significantly between groups $\mathrm{E}$ and $\mathrm{C}$ (Table 1). The females of both groups grew faster $(P \leqslant 0.006)$ and consumed less feed per $1 \mathrm{~g}$ weight gain than did the males $(P \leqslant 0.006)$.

Mixing the egg yolk with pelleted feed resulted in the $\mathrm{E}$ rabbits consuming approximately three times more cholesterol than the controls (Table 1) but this was not accompanied by an increase in the concentration of total plasma cholesterol. After consuming 64 egg yolks the rabbits had an even lower mean total plasma cholesterol than the control ones (Table 2). There was a significant diet $\mathrm{x}$ sex interaction effect in respect to total plasma cholesterol after the period of feeding egg yolk, $(P \leqslant 0.013)$. The females in the group fed egg yolk demonstrated a greater increase of total plasma cholesterol than males, but the opposite tendency was observed in the control group (Table 2). The correlation coefficients between the investigated traits, calculated separately within the $\mathrm{E}$ and $\mathrm{C}$ groups were mostly inconsistent (Table 3 ).

Not one of the rabbits fed egg yolk developed atherosclerosis. The lack of any effect of feeding egg yolk cholesterol on atherosclerosis in this experiment was 
TABLE 1

Consumption of food with and without egg yolk and weight gain in male and female rabbits

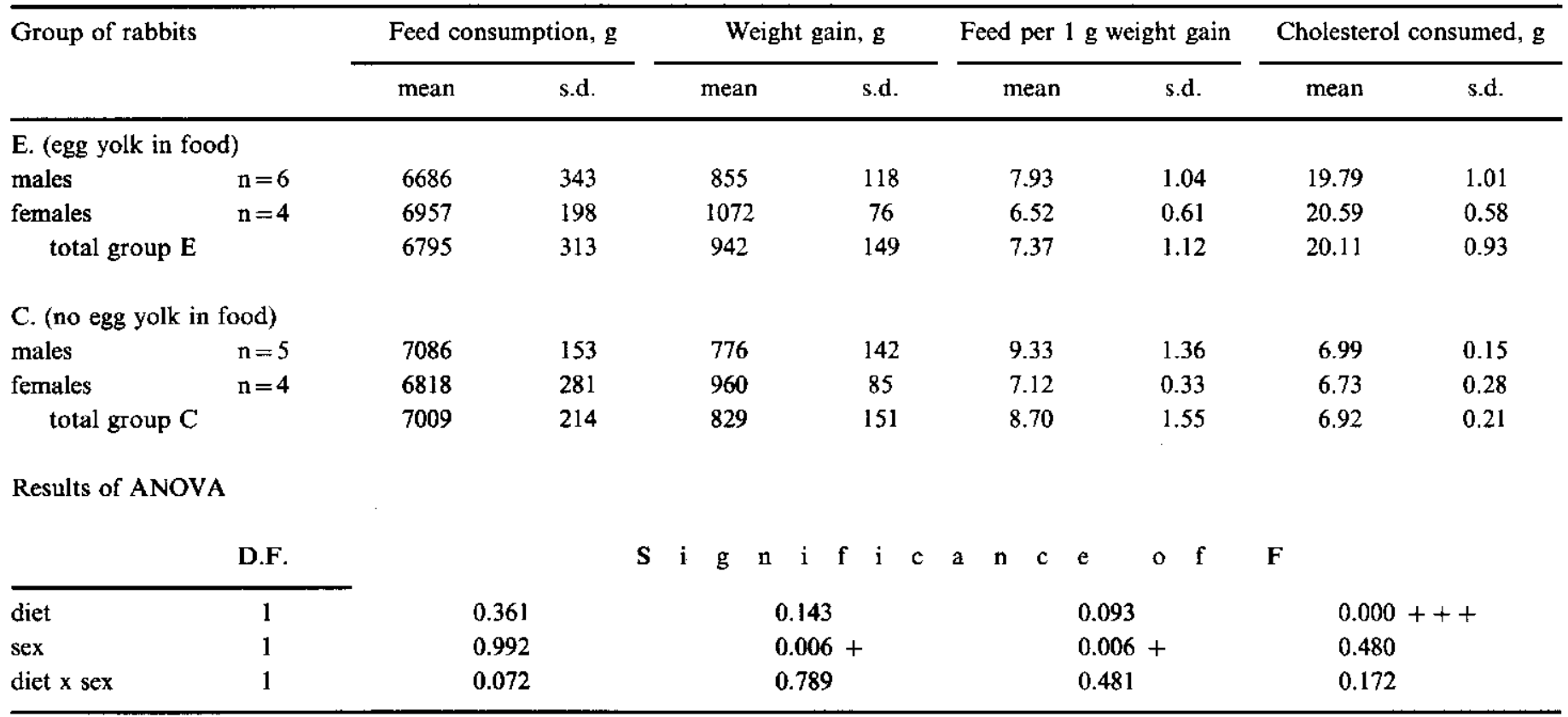


TABLE 2

Total plasma cholesterol in male and female rabbits

Group

of rabbis

mean

$n=6$

$n=4$

total group E

C (no egg yolk in food)

males

females

$\mathrm{n}=5$

$n=4$

127.9

112.8

123.6

108.6

136.9

121.5

total group C

Results of ANOVA

D.F

\begin{tabular}{ll}
\hline diet & 1 \\
sex & 1 \\
diet $x$ sex & 1
\end{tabular}

Total plasma cholesterol, $\mathrm{mg} / 100 \mathrm{ml}$

Increase in total plasma cholesterol,

after experiment

s.d.

mean

s.d

36.6

30.5

116.1

187.5

19.3

38.3

7.4

58.2

33.2

144.4

45.1

24.5

48.6

$\begin{array}{ll}21.3 & 189.8\end{array}$

189.8

61.9

61.9

64.5

62.5

172.1

62.9

48.5

8.0

57.5 
TABLE 3

Correlation coefficients between traits investigated

\begin{tabular}{|c|c|c|c|c|c|c|c|}
\hline \multirow{3}{*}{ Traits } & & \multicolumn{4}{|c|}{ Total plasma cholesterol } & \multirow{2}{*}{\multicolumn{2}{|c|}{$\begin{array}{c}\text { Increase of tota } \\
\text { plasma } \\
\text { cholesterol }\end{array}$}} \\
\hline & & \multicolumn{2}{|c|}{ bcforc experiment } & \multicolumn{2}{|c|}{ after experiment } & & \\
\hline & group & E & $\mathrm{C}$ & $\mathrm{E}$ & $\mathrm{C}$ & $E$ & $\mathrm{C}$ \\
\hline Cholesterol consumption & & .11 & -.21 & .40 & .03 & .29 & .15 \\
\hline Weight gains & & .39 & -.22 & .69 & $-.91^{*}$ & .35 & $-.88 *$ \\
\hline Feed per $1 \mathrm{~g}$ gain & & -.41 & .10 & -.64 & $.87^{*}$ & -.29 & $.90^{*}$ \\
\hline $\begin{array}{l}\text { Total plasma cholesterol } \\
\text { before experiment }\end{array}$ & & & & .30 & .42 & -.46 & -.10 \\
\hline
\end{tabular}

* significant at $\mathrm{P}<0.05$

rather surprising, since feeding one egg yolk daily for a period of approximately 60 days was successfully used as a method for inducing atherosclerosis in rabbits by Cornhill and Roach (1974). However, the results of experiments on the effect of egg consumption or cessation of egg consumption on serum cholesterol are contradictory. While in some works (Slater et al., 1976; Kummerow et al., 1977; Porter ct al., 1977; Flynn et al., 1979; Voster et al., 1992) egg consumption was demonstrated to have no effect on total serum cholesterol in humans, Bronsgeest-Schoute et al. (1979) ascertained a small but significant decrease in serum cholesterol after removal of eggs from the diet of habitually egg-eating people. According to Beynen and Katan (1985), after 3 weeks during which no eggs or egg-containing products were consumed, the serum cholesterol decreased by $6-16 \mathrm{mg} / \mathrm{dl}$ in one and by $12-14 \mathrm{mg} / \mathrm{dl}$ in another experiment and individual responses varied from -39 to $+19 \mathrm{mg} / \mathrm{dl}$. On the other hand, Vizioli et al. (1988) found a decrease of total serum cholesterol when beef and pork in the diet of elderly people were completely replaced by eight eggs per week. Beynen et al. (1986) suggest that in animals individual differences in response to dietary cholesterol are greater than in man, due to the existence of hypo- and hyper-responders. In a majority of experiments on humans, the investigations concentrated on the effects of eliminating eggs from a diet rather than on the effect of including eggs into a diet that had previously not contained eggs at all. In the experiment by Richard et al. (1990), young goats receiving cholesterol as egg yolk had a significantly higher cholesterol concentration in blood plasma than did goats supplemented with crystaline cholesterol.

As one of the possible explanations for egg intake having no effect on serum cholesterol Vizioli et al. (1988) and Voster et al. (1992) suggest that the phospholipid in eggs may be hypocholesterolemic and may counteract any possible hypercholesterolemic effect of the cholesterol in eggs. 
In conclusion, the present experiment demonstrated that a three-fold increase of cholesterol consumption resulting from mixing egg yolk with normal feed had no significant effect on total plasma cholesterol and no visible atherosclerosis - promoting effect in rabbits.

\section{ACKNOWLEDGEMENT}

We are grateful to Mrs. Anna Stawicka for her care of the experimental animals

\section{REFERENCES}

Beynen A.C., Katan M.B., 1985. Reproductibility of the variation between humans in the response of scrum cholcstcrol to cessation of egg consumption. Atherosclerosis, 57, 19-31

Beynen A.C., Katan M.B., van Zutphen L.F.M., 1986. Hypo- and hyperresponders to dietary cholesterol. In: A.C.Beynen (Editor), Nutritional Effects on Cholesterol Metabolism. 'Transmondial, Voorthuizen, 99-109

Bronsgecst-Schoute D.C., Hermus R.J.J., Dallinga-Thie G.M., Hautvast J.G.A., 1979. Dependence of the effects of dietary cholesterol and experimental conditions on serum lipids in man. III. The effect on serum cholesterol of removal of eggs from the diet of free-leving habitually egg-eating people. Amer.J. Clin. Nutr. 32, 2193-2197

Brown W.V.,1990. Dietary recommendations to prevent coronary heart discase. Ann. New York Acad. Sci. 598, 376-388

Cannon G.,1990. Healthy cating. The Experts Agree HMSO, London

Cornhill J.F., Roach M.R., 1974. Quantitative method for the evaluation of athcrosclerotic lesions. Atherosclerosis 20, 131-136

Flynn M.A., Nolph G.B., Flynn T.C.. Kahrs R., Krause G., 1979. Fffect of dietary egg on human serum cholesterol and trigyccrides. Amer. J. Clin. Nutr. 32, 1051-1057

Griffin H.D., 1992. Manipulation of egg yolk cholesterol: a physiologist's view. World Poultry Sci. J. $48,101-112$

Hargis P.S., 1988. Modifying egg yolk cholestcrol - a revicw. World Poultry Sci. J. 44, 17-29

Jezierski T.. Mckking P., Wiepkema P.R., 1993. Handling and diet induced atherosclerosis in rabbits. Lab. Anim. 27, 235-239

Kummerow F.A., Kim Y., Pollard J., Hull J., Illnow P., Dorossiev D.L., Valek J., 1977. The influence of egg consumption on the serum cholesterol level in human subjects. Amer. J. Clin. Nutr. 30, 664-673

Porter M.W., Yamaneka W., Garlson S.D., Flynn M.A., 1977. Effect of dietary cgg on serum cholesterol and triglyceride of humanmales. Amer. J. Clin. Nutr. 30, 490-495

Richard M.J., Lynn D.D., Jacobson N.L., 1990. The domestic goat: a useful model to determine effects of diet and excercise on cholesterol accumulation in the body. Comp. Biochem. Physiol. $95 \mathrm{~A}, 2,275-280$

Romeis B., 1968. Mikroskopische Technik. Munchen-Wien R.Oldenburg Verlag, 259

Sieber R., 1993. Cholesterol removal from animal food - can it be jusified?. Lebensmittel-Wiss. Technol. 26, 375-387 
Slater G.J., Mead J., Dhopeshwarker G., Alfi-Slater A.B., 1976. Effects of eating eggs on plasma cholesterol levels in young and middle-aged men. Nutr. Rept. Int. 14, 249-253.

Vizioli A., Schipani A., Capriotti L., Biagiarelli C., Bevilacqua L., Menteleone A., 1988. Changes in the lipid spectrum after an egg diet. Clin. Diet. 15, 205-212

Voster H., Benade A.J.S., Barnard H.C., Locke M.M., Silvis N., Venter C.S., Smuts C.M., Engelbrecht G.P., Marais M.P., 1992. Egg intake does not change plasma lipoprotein and coagulation profiles, Amer. J. Clin. Nutr. 55, 400-410

\section{STRESZCZENIE}

\section{Wpływ żywienia żóltkiem jaj na poziom cholesterolu calkowitego i arteriosklerozę u mlodych królików}

Pierwotnym celem doświadczenia bylo badanie roli czynników behawioralnych i emocjonalnych w powstawaniu arteriosklerozy wywolywanej podawaniem cholesterolu w paszy u królikow. Królikom doświadczalnym (grupa $\mathrm{E}, \mathrm{n}=10$ ) podawano dziennie $130 \mathrm{~g}$ standardowej paszy granulowanej z dodatkiem 1 źółtka jaja kurzego. Króliki kontrolne (grupa $\mathrm{K}, \mathrm{n}=9$ ) otrzymywały tą samą dawkę paszy bez żółtka. Ogółem kroliki z grupy E spożyły 64 żóltka w ciągu 2 miesięcy. Przed i po okresie doświadczalnym w osoczu krwi królików oznaczono poziom cholesterolu całkowitego. Stopien arteriosklerozy oznaczano ilościowo jako procent powicrzchni aorty ze zmianami miażd’ycowymi. Dodawanie jółtka do pasły spowodowało, że króliki z grupy E pobrały w okresie doświadczalnym 20,1 g cholesterolu, podczas gdy króliki kontrolne po $6,9 \mathrm{~g}$ cholesterolu zawartego w paszy standardowcj. Nic stwierdzono istotnego wpływu podawania żółtka na poziom cholesterolu calkowitego w osoczu. Stwierdzono istotny wpływ interakcji dieta x płeć na poziom cholesterolu po okresie doświadczenia. U ładnego \% królików doświadczalnych i kontrolnych nie stwierd\%ono widocznych objawów arteriosklerozy w aortach. 